Canadian University Music Review

Revue de musique des universités canadiennes

\title{
Text, Context, Music
}

\section{Istvan Anhalt}

Volume 9, numéro 2, 1989

URI : https://id.erudit.org/iderudit/1014904ar

DOI : https://doi.org/10.7202/1014904ar

Aller au sommaire du numéro

Éditeur(s)

Canadian University Music Society / Société de musique des universités

canadiennes

ISSN

0710-0353 (imprimé)

2291-2436 (numérique)

Découvrir la revue

Citer cet article

Anhalt, I. (1989). Text, Context, Music. Canadian University Music Review /

Revue de musique des universités canadiennes, 9(2), 1-21.

https://doi.org/10.7202/1014904ar

All Rights Reserved (C Canadian University Music Society / Société de musique des universités canadiennes, 1989
Ce document est protégé par la loi sur le droit d'auteur. L'utilisation des services d'Érudit (y compris la reproduction) est assujettie à sa politique d'utilisation que vous pouvez consulter en ligne.

https://apropos.erudit.org/fr/usagers/politique-dutilisation/ 


\section{TEXT, CONTEXT, MUSIC}

\section{Istvan Anhalt}

Consider this. Someone is seized by fear. What happens? He flees. Or, he freezes into a posture, holds his breath; complete silence. He might emit now a hoarse, loud, scream. Another, in a similar predicament, might just jabber and giggle helplessly. Or, we might hear the distant whine of a child. In another situation someone pants: / ha/ / ha/ / ha/ . . . breathy and rhythmical. When there is less threat and more control, we might hear a guttural voice uttering: "No!" or "I am scared". In another context we are members of a congregation that recites in a random cluster of monotones:

"Give ear to my prayer, O God;

and hide not thyself from my supplication."

"Fearfulness and trembling are come upon me, and horror hath overwhelmed me."

[ Psalm 55; 1,5]

Or imagine hearing this in a fictitious song performed in a recital that never was:

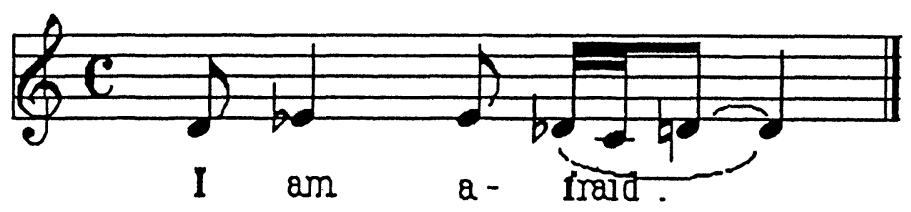

Figure 1. :

Or, should we hear an exaggeratedly nasal voice intoning with a flourish "Oh, how dreadful," or in an opera of the absurd the tremulous yodeling 
of a half-clad buffoon complaining about being pursued with evil intent, we would be inclined to think that the message is about quite something else, than fear.

In all these experiences, save one, there is sound and within it one or another kind of text (or, in the case of the complete silence of the first one, a telling absence of both). These reflect back on, and inform about affect, thought, person and situation.

What is a "text"? In a narrower sense, in the present framework, one could suggest that "text" refers to words (normally existing in a written form) set to music by a composer. As this formulation could prove to be somewhat confining, I am suggesting a different one. I will say that a text, uttered, or written, stands for some kind of mental activity, for some kind of experience, which it is able to express as a result of conscious design, reflex action, or instinct, or a combination of these, in a certain situation (context). To this we may add, that some texts can, and do, become parts of musical compositions. Now, before we focus on the relationship between "text" and "music", let us think of the notion of "text" in this broader sense.

We all have stories regarding this. I shall recount two recent ones.

A few weeks ago I saw a young woman on the train with Plato's Republic held open in her hands. Intermittently, she read and looked up absentmindedly, or so it appeared. Was it an instance of daydreaming, or conversely a concentrated dialogue with Plato? I asked myself. Could it have been a contest between the text of the book and another one possibly unrelated to Plato, a contest that might have eventually resulted in a written essay on some aspects of the Republic, or alternately, in a non-verbal, or verbal, act that had little, or nothing, to do with Plato and which might eventually (or never) be expressed in writing? Or it might have resulted in both.

The second story is about another young woman, a student on our campus, whom I saw sporting an engineering student's jacket, with the standard oversized lettering on the back: APPLIED SCIENCE. Not quite a tattoo, but akin to a tribal mark, nevertheless; perhaps a somewhat over-eager celebration of belonging. The two stories are unrelated. Yet, in both one can see a relationship between a written text, visible to the observer, and another one that goes on in the mind, and which we can only guess at.

However suggestive they may have been, neither one of these little "scenes" included the modality of oral utterance (which was nevertheless 
present in its "non-markedness") that constitutes a vital dimension of human experience and of interpersonal action between individuals and groups and which often serves also as an intermediate link between thought and feeling on the one hand, and a written text, on the other. I would like to pause here and enlarge on this. I am searching for a suitable paradigm. Yes, the way some Jewish thinkers thought about the Bible might be a good example for the intimate inter-connectedness of these three modalities. Take, for example, Isaac the Blind, the early Kabbalist mystic, who lived in or near Narbonne from about 1165 to 1235 and who "was regarded as the central figure of the Kabbalah during his lifetime" (G. Scholem, 1974: p.45). He speculated about the "three degrees of manifestation of the Torah - The Primordial Torah, the Written Torah and the Oral Torah." (G. Scholem, 1987: 287). Of the Primordial Torah Isaac wrote: "In the right hand of God were all the engravings [i.e. the inner most marks, which are, as yet, not real forms] that were destined one day to proceed from potentiality to actuality" (ibid.). Of the other two forms he says: " ... the Written Torah cannot adopt corporeal form, except through the powers of the Oral Torah: that is, that the former cannot be truly understood without the latter . . " (ibid.: 288). One appears to be justified in reading this as an indication of a deep psychological-epistemological insight, as well as an allusion to the well-known traditional practice of layers upon layers of commentaries upon the Torah accumulating over the centuries, which, themselves, in time, have become a "companion tradition, an "oral Torah" . 1 The "oralness" of the Jewish sacred texts has been considered from yet a different point of view by modern biblical scholarship focussing on literary and historical criticism. Some scholars stressed "the central role of oral traditions and the accuracy of their transmission in ancient times. They claim that oral transmission influenced the sources even after they were reduced to writing" (ibid.: 358). So much about one example of the many that could be cited in illustrating the interdependence of thought, and transmission of same, through oral utterance or by writing.

"Language is the Flesh Garment, the Body of Thought." So Carlyle wrote in Sartor Resartus (E. Sewell, 1964: 47).

Garment ... textile . . texo. . . My thoughts wander . . . I move backwards in time. In illo tempore ... Y Yes, now I see . . a woman,

1 See the entry "Torah", by E.E. Urbach in M. Eliade, ed. in chief, The Encyclopedia of Religion, (New York: Macmillan, 1987), Vol. 14, p. 558. 
seated in front of her loom, weaving. The warp, threads of the woof, more yarn on spindles, uncarded wool in a corner ... A timeless picture. How long did it take us to get to that level of civilisation? And when did the leaps to metaphor, such as these, occur: from weaving to thinking; from spinning yarn to spinning forth a line of thought; from weaving a length of cloth, to weaving an argument, the threads of a tale into a story, and into a text, finally. Already in Roman times texo had a number of derivatives. For example, contexo meant to weave together; subtexo to cover, to draw together under; praetexo to weave before, to adorn, to cover, to conceal; and the curious retexo, which does not appear to have been preserved in English, or in French or Italian. It meant: to unweave, unravel, and also to weave again (A. Ernout et A. Meillet, 1932: 995-6) and Cassel's Latin Dictionary (rev. by J.R.V. Marchant and J.F. Charles, 1955: passim). There are numerous others.

A piece of woven cloth, an entire garment worn for the purpose of protection, or concealment, or enhancement, or any combination of these, might also be seen as a symbol: that of the wearer's awareness of his/her own being, his or her own "thisness" (haecceitas) or at the least a significant component thereof. (A double example of this can be seen on a dyptich by Stefano di Giovanni Sassetta, in the National Gallery in London, showing in one of the panels St. Francis of Assisi holding a garment in his hands while contemplating to becoming a soldier. The other panel depicts him having divested himself of his robe, signifying a complete breaking of family ties and devoting himself to the Church.)

Spinning and thread are also central metaphors in the myth of the Moiras, as they, according to legend, exercised control over the lifespans of humans. Numerous other myths and legends in Greek, Norse, Anglo- Saxon, Slav, Celt, Hindu and Persian mythologies also make reference to spinning and the thread, or to bond and binding. ${ }^{2}$ The word "text" contains all these relationships and many others besides. Its semantic scope is vast. Since "text" is none other than an instance of language actualised, what is at hand, then, is "an inexhaustible, abundance of manifold treasures" (L. Hjelmslev: 1969: 3). It (language) is "the instrument with which man forms thoughts and feeling, mood, aspiration, will and act, the instrument by whose means he influences

2 See R.B. Onians: The Origins of European Thought about the Body, the Mind the Soul, the World Time, and Fate, (Cambridge: Cambridge University Press, 1951), passim. 
and is influenced, the ultimate and deepest foundation of human society" (ibid.).

How do composers of our time respond to such a vista, such a horizon as this with respect to the choice of texts (some write their own) for their compositions? To attempt here to present a systematic, exhaustive and detailed overview of all the various kinds of texts one recalls having encountered in the repertoire is beyond the scope of my account. What I am proposing instead, is but a brief, provisional and non-systematic listing of certain text-types.

As to objective, theme, approach and/or genre, I recall texts that

1. Expose an idea; tell a story; depict a situation; show a series of actions; etc.

2. Those that praise, criticize, mock, accuse; etc.

3. Those that show identification with a creed, an attitude, an ideology, or an episteme; ${ }^{3}$

4. Those that depict the world of dreams, the irrational, or the psychopathological;

5. Those that show archetypes or archetypal situations; enact myth, or engage in mythopoiesis;

6. Those that focus on the deictic (that is the space-time) co-ordinates of a situation;

7. Those that are arrived at through collage or assemblage techniques, borrowings;

8. Those that search the past; either "in illo tempore", the Orphic past, or early historical eras, or ontogeny;

9. Those that employ quasi-magical texts, repeated formulas, slogans, or text deconstructions;

10. Those that are borrowed from traditional cultures, Western, or non-Western;

3 An epistemological field. See M. Foucault, The Order of Things, (New York: Vintage Books, 1973) p. xxii. 
11. Documentaries, or pseudo-documentaries, Hörspiels;

12. Ex post facto text grafts, tropes;

13. Those in which paralinguistics predominate;

14. Vocalisations, and articulatory process-centered works in which body, 'text' and music merge into one. ${ }^{4}$

As to authorship one notes

1. Adopted texts (sacred or profane);

2. Composer's texts;

3. Librettist's texts;

4. Hybrid texts assembled from diverse sources; and

5. Found texts.

As to languages, the repertoire shows

1. Unilingual works;

2. Polylingual ones;

3. Works in a counterfeit language (mimicking a natural language); or

4. In an artificial language; glossolalia;

5. Age-specific, class-specific, etc., idiosyncratic utterances;

6. Animal language (zoo-semiotic) imitations;

7. Onomatopoias;

8. Buccal play;

9. Various combinations of the foregoing.

4 Some of these categories would benefit from being looked at from the point of view of the 'speech acts', as conceptualized by J.L. Austin and others. 
Now a few examples.

Edoardo Sanguineti begins his vast collage-libretto of laborintus II for Berio this way: "In that part, in that part of my memory, in that part of the book, in that part of the book of my memory, incipit vita nova," and with this, in one arc of a gesture, creates the potential for a system of relationships that reminds me of a vast cloverleaf intersection of roadiways at the approach to a large city. The complete text appears to me as a large and dynamic assemblage of memory 'places', topoi that might have been at the time of composition of some import to the librettist, and to the composer. In it, are mingled references to etymology, to historical loci, to religious history, including biblical genealogy, and to Dante, himself metamorphosed here into a psychopomp. Diachrony is fused into synchrony, as well as distant conceptual fields to each other, by the sudden appearances of elliptical phrases such as "from first communion to the Treasury Department: from the darkness which ever surrounds our lives to the $4 \%$ profit ... . from the square root to the Trojan horse, from the lapsus linguae to Russian Revolution . ..." Then suddenly place names appear: "to Brussels, to Paris"to "Mills College, to Santa Fé, to Mass Avenue", channeling into a list of street addresses, presumably of autobiographical relevance (do these stand here as symbols of human relationships?), judging from the inclusion here of 'Via Moscati 7', which I happen to know to have been, at one time, the address of Cathy Berberian, Berio's first wife. The whole mélange, at one point, suddenly begins to take on the character of an 'insight' into a working mind itself, a mind that acts as a theater of memories reminding one, in yet another instance of an epistemological regression, of the numerous forms of a learning device called 'memory theatre', that was highly prized in the Renaisssance as a mnemonic instrument, but even more so as a compendium for one or another episteme. ${ }^{5}$

The very title of the Sanguineti-Berio work puts the listener on guard: here one enters (or descends into) a labyrinth (or is it an inferno?). Now this "figure" - that of the labyrinth - is a recurring one in the contemporary repertoire of works for the voice. Another notable example of it is Maurizio Kagel's Anagrama. Its text is but a single

5 See in this regard, F. Yates' The Art of Memory, (London: Routledge and Kegan Paul, 1966) and also M. Foucault's The Order of Things, (New York: Vintage Books, 1973). 
sentence: In girum imus nocte et consumimur igni. It speaks of loss of direction, and as such contains the connotation of an aporia, a "theme" larger still than the labyrinth. Another feature here is the palindromic structure that brings within itself the flavour of a magical conjuration. All these are placed in a setting that features, among other affects, much hilarity (another instance of playing with topoi?). ${ }^{6}$ The labyrinth as a metaphor can also be found in the works of R.M. Schafer, Maurice Ohana and David Keane, among others.

Some composers keep to a theme for a long time, work after work. They seem to be engaged in writing a carmen perpetuum. One such composer is R.M. Schafer, many of whose texts, like some of Erik Bergman's, and Harry Somers', deal with the history of Eastern Mediterranean lands and beyond, and with the influences that shaped the Judeo-Christian world-view there, including the Cretan, Egyptian, Zoroastrian, Manichean, Tibetan and Hindu. In some of Schafer's texts this theme is woven together, as was cited, with the myth of the labyrinth and in particular with that of Ariadne, the girl of the guiding thread, who appears, dies, and reappears again in various guises in a series of metempsychoses. The numerous other related themes of Schafer's include alienation, and the irrational, with echos from Novalis, E.T.A. Hoffmann, Rilke, Nietzsche, Freud and Jung, all fusing into a personal, powerful and unified voice.

George Crumb is in the process of painting over the years a large canvas through setting many texts by Federico Garcia Lorca that is characterized by great dramatic intensity and an exceptionally wide spectrum of tonal colour.

Peter Maxwell Davies, in work after work gives, with profound empathy, expression to his understanding of and feeling for the spirit of the people who live on the Orkney Islands.

John Beckwith's texts come from many sources, but most of them coalesce into a large picture: a very individualistic representation - at times dream-like, at times near documentary - of certain facets of 19th century and present-day English Canada. One of his favourite text-types is the collage, and his settings amount to an individual and persuasive blend of directness, recherché simplicity, an occasional

6 S. Chatman: "How Do We Establish New Codes of Verisimilitude" in W. Steiner ed. The Sign in Music and Literature (Austin: University of Texas Press, 1981), p. 30. 
intentional roughness "at the edges", alongside much learned invention. Beckwith's view of his favourite place-time theme has also a characteristic tinge of a play-like contemplativeness, as if allowing an exceedingly bright, precocious, say, twelve year old to "speak out" of the mature mind of the adult he has developed into.

Trevor Wishart's carmen is a search into the very nature of the musical voice itself, and the compositions that have resulted from this to-date are among the most inventive ones of their genre. Following his Anticredos of 1980, he was and continues to be at work on a series of pieces with the general title VOX and has written, so far 4, of them: nos. $1,2,3$, and 5 . These pieces show a wide spectrum of compositional techniques related to the voice, specifically including a fairly recently developed one: composing for and with the vocal articulatory process itself as an unified endeavor, instead of conceiving composition as consisting of a pre-existent text and its subsequent setting to music. Complementary semiotic elements in these pieces include musique concrète and computer simulations of atmospheric, water and various zoo-semiotic sounds, recorded bird-song and human imitation of diverse animal sounds. One also hears, live, from the members of the small vocal ensemble for which Anticredos, Vox 1, and 2 were composed, phoneme sequences, brief utterances in an invented language, as well as imitations of non-Western idioms. The dominant element in these works, however, appears to be human vocal sounds which are produced by what Wishart and others call 'extended vocal techniques': vocal processes, timbres, gestures, their relationships to each other, as well as to the other materials present. The composition of these pieces was facilitated by Wishart's experimental work leading to the development of a personal 'extended vocal techniques' repertory and by the impressive skill in the performance of the same by himself. But, as we speak of the relative novelty of this approach, and the kinds of sounds it produces and composes with, it is essential that we remind ourselves that it is, by no means, without precedents, some of which are very old, some most likely even as 'ancient' as man himself.

The great hassidic teacher, Pinhas of Koretz, for example, taught this early in the 19th century: " . . . the holy Torah was originally created as an incoherent jumble of letters ... Only when a certain event occurred in the world did the letters combine to form the words in which the event is related. . . If another event had occurred in its place, other combinations of letters would have arisen ..." (G. Scholem, 1965: 76-77). So, once again, the arrow points from the vocal signal back to the feeling or thought that has engendered it. This idea, applied to the work of Wishart, could perhaps be understood as indicating that he is 
searching for an artistic 'pseudo' recreation of a very early stage of human linguistic competence, a quasi-phonetic, more or less physiologically - emotively conceived/motivated stage that can be regarded as only holding the potential for evolving a broad variety of phonemic, phonological and morphemic repertories that could, and would, develop synchronously and in accord with the evolution of concepts in the mind. In this sense Wishart's compositional gesture, ignoring the more or less traditional notions of text with its creative contraints as to 'degrees of freedom of choice' and opting for a quasi-primordial, hoped-for maximally 'free' repertoire, instead, is a powerful, yet, paradoxically, also a severely constrained one.

This search for the well-springs of expression through thinking, instead in terms of the sign vehicle, in terms of the vocal process itself that expectedly produces it, has other notable antecedents. Homer referred to thinking as speaking and "located [it] sometimes in the heart, but usually in the ... phrénes . . the lungs or the diaphragm" (R.B. Onians, 1951: 14). "It is by his thymós (spirit, temper) in this phrénes, or by what is breathed into them by some god, that a live poet divines" (ibid.: 66). B. Malinowski, reported that the Society Islanders conceive of thinking as 'speaking in the stomach'. And about the natives of New Guinea he wrote that

The mind, nanola, by which term intelligence, power of discrimination, capacity for learning magical formulae and all forms of non-manual skill are described as well as moral qualities, resides somewhere in the larynx.

[ ibid.: 14 ]

Other similarities can also be found in certain shamanistic practices and in Graeco-Egyptian oral magic (Anhalt, 1984: 186-96).

There appears to be yet another possible source of influence on Wishart, and it seems to me to be of first importance: it is early childhood. Roman Jakobson wrote than in infancy "The actual beginning stages of language as is known, are preceded by the so-called babbling period, which brings to light in many children an astonishing quantity and diversity of sound productions." "A child,"he continues "during this babbling period, can accumulate articulations which are never found within a single language or even in a group of languages." (1968: 21). There is reason to believe that in Wishart's Anticredos, Vox 1 and in parts of Vox 2, a desire to rediscover some of this articulatory diversity of infancy, for some reasons, including perhaps its symbolic connotations, plays a role. 
Now, a new focus: 'context'. How to begin? Perhaps again with a story. Recently, reading the section on travel in a Saturday newspaper, I noticed a photo showing a handsome couple in one of the beautiful courtyards of the Alhambra, in Granada. The caption under it read: 'Put yourself in the picture.' It occurred to me that the couple in the photo could be seen as being its intended 'real text', framed by the suggestive environment, which we may term as the 'context'. The composite of these, together with the caption, formed another, compound, text which functioned as an item in the context of the entire travel section, which itself, was but one of the several sections that constituted the entire newspaper. The latter's 'text', in turn, could be read in a number of contexts: all the media messages that were issued on that day, etc. What matters here is the process that changes text and its context into a compound new text, which, in turn, is 'read' in one, or another, still broader context, and so on, seemingly without end.

A context might expose, point out, confirm and reinforce the primary, obvious, thrust of a text, but just as well it might give it a strange twist that sets up an opposition between the two, at times with a startling effect. In 18th- and 19th-century still-lifes one might expect to see objects that were likely to be found, according to assumed degrees of probability and serendipity, on a table in a given place at a given moment. Such assemblages inform and suggest all sorts of extrapolations, that is, contexts. Picasso's and later Kurt Schwitters' collages, and still later Joseph Cornell's boxes, suggest different junctures, contexts. All of these test the imagination. So did Klee when he advised his students in the Bauhaus to collect objects on the street and, subsequently, assemble these into 'works of art'. The exercise appears to have been aimed at weakening the hold of the unthinking response and at mobilizing to a fuller extent the students' imagination. It was based, insightfully, and also perhaps with the help of remembering some of Leonardo's thoughts about random visual patterns, on the capabilities of the vast combinatorial power of the mind.

The mystical discipline developed by the Spanish Kabbalist Abraham Abulafia (1240 - after 1292), which he calls Hokhmath ha-Tseruf i.e. 'science of the combination of letters'is of considerable relevance here as an early antecedent. (A masterful description of this technique may be found in G. Scholem, 1954: 130-8.) Of particular interest is that Abulafia, himself, compared this practice to musical composition. Klee's experiment, alongside similar ones by some Dadaists, and 
especially by surrealists such as André Breton, and Finnegans Wake by Joyce, were among the 'antecedents' that led to the work of Berio whose preference for collage texts brought forth works like Passaggio, Sinfonia, Coro, besides the already commented upon laborintus II.

Looking at the recent British repertoire, two works, both of which are based on large-scale collage-type librettos, stand out. Tippet's text for The Mask of Time is an assemblage of somewhat disparate elements, in part borrowed and in part written by the composer himself. The work is succeeding largely on account of the unifying power of the music. The strong appeal of the Birtwistle-Zinovieff opera, The Mask of Orpheus, (regrettably, I was, so far, unable to hear it) appears to be due, in some measure, to the librettist's and composer's bold conceptualization of an unified new context for a whole array of mythic and philosophical material which they related to their interpretation of the 'Orpheus' idea.

Kagel in his recent The Passion of St. Bach creates a surprising context by positing a number of startling analogies and transformations. This substantial and 'serious' work harks back, of course, to Bach's own Passions in which the story of the suffering of Christ is the theme, and text, and the compositions the artistic, 'distanced', context. In turn, the Passions, in their totality, form a part of Bach's total vocal/choral output, the latter being a sort of carmen perpetuum in the context of Bach's life, not only in a musical, but also in a spiritual sense. This life, in turn, has become a theme, a subject for texts, so realized since a long time by historical musicologists, and now also by Kagel in a work in which Bach himself - the composer of Passions - is the central figure, the very 'text', of a passion, based on his life.

My own Foci (1969) is a new context for a fairly wide range of different pre-existent texts in 9 languages, uttered live or via pre- recorded tapes, by over a dozen singers and speakers. These texts come from a dictionary of psychology, the Old Testament, the Zohar, the Genevan Psalter, the Ishtar legend, a Voodoo ceremony, to which I added an oath formula, words related to quantification and snatches of colloquial English that I either read or overheard.

Ben Johnston's Vigil has no text at all; at least not one that is to be 'set' and uttered in a performance. The 'score' consists only of the description of an action plan for improvisation by a choral group. The plan calls for the designation of a leader who is instructed "to undertake an all-night vigil ... on behalf of an oppressed group of people . . . . The vigil should entail a mild discomfort." After the lapse of a certain 
period of time, this leader is to collect a selection of writings or sayings of "dedicated members of the oppressed group . . ." These fragments are then studied and meditated upon by the members of the entire improvisation ensemble, etc. In short, the work is nothing but a context for a group activity that is expected to produce (or it is hoped it will do so) a satisfactory realization of the idea behind the work.

B. Malinowski wrote that "A statement spoken in real life is never detached from the situation in which it has been uttered. For each verbal statement by a human being has the aim and function of expressing some thought or feeling actual at that moment and in that situation ... Without some imperative stimulus of the moment, there can be no spoken statement ... a word without linguistic context is a mere figment and stands for nothing by itself . . . an utterance has no meaning except in the context of situation." (G.K. Ogden \& I.A. Richards, 1946: 37)

The expanding patterns of reciprocal interpenetrations between Western and non-Western societies and civilizations during the 20th century give a new emphasis to Malinowski's statement. Borrowings from non-Western cultures by Western artists are a part of this vast movement of ideas. A recent and interesting example for this is Choralis I, II, III by Nigel Osborne in. which he combined Western-type procedures and materials with a Tuareg medicinal chant, a Turkish harvesting song and the Balinese ketjak, into an impressive amalgam. He set out to achieve this first by expertly transcribing these models into Western notation. Then he proceeded with imaginative transformations of these and ultimately by recombining these with other elements into a convincing new 'whole'. The circumstance that the exorcistic dimension of the authentic ketjak could only be alluded to here (at least that was the impression I got while listening to a tape recording of a performance of the work) was, of course, unavoidable, given the nature of the resulting new work and its context. But this loss of authenticity may be regarded, at least from the vantage point of view of a Western listener, as having been compensated for by the substance of the new work and by the implications of a new context. Similar transfers are also likely to entail the severing of some relationships, while bringing about hitherto un-thought-of new ones. This can be, at times, an intricate and also a rewarding enterprise. Osborne showed boldness in undertaking it, and succeeded admirably.

In his recent large-scale mythopoeic enterprises $(R a$, and The Princess of the Stars) R.M. Schafer expanded his notion of context to include a predetermined place and a predetermined time of the day, or the night, 
and even the number of those who can, nay must, participate in the performances that take the form and character of a new ritual. In $R a$ the locale was the impressive modern edifice of the Ontario Science Centre in Toronto. The myth of the Sun-god was re-enacted by a fairly large cast and 75 co-celebrants (the audience) in a total audio-visual experience that included an Egyptian style midnight meal, and an hour of rest, the whole lasting 11 hours from dusk to dawn. In The Princess of the Stars the legend upon which the work is based is Schafer's own. The work is presented in the open, along the shoreline of a lake. (The premiere took place in the Canadian Rocky Mountains.) It begins while it is still dark and ends sometime in the morning. Schafer says this in the introduction to the work: "What is the effect of treating nature in this way? By mythologizing it we intensify our experience of it." By this, I presume, Schafer says that through this process an 'outer' landscape is made to merge with an 'interior' - mythical - 'scene' in the mind; thus, nature and man, instead of being antagonists, may be, once again reintegrated into a unified whole.

Contemporary philosophy and linguistics, also, are showing concern for context or situation. This seems to be of relevance to music also. According to Mario Bunge, for example, "like meaning, understanding is contextual: it does not occur unless a whole constellation of related items is activated" (1985. Vol 7, III, Part 2: 268-9). Hans-Georg Gadamer writes about the 'concept of situation' that represents "a standpoint that limits the possibility of vision. . . . An essential part of the concept of situation is the concept of 'horizon". Elsewhere he coins the expression: the 'fusion of horizons' (1975: 269, 273). According to Paul Ricoeur in Hermeneutics and the Human Sciences, "What the text signifies no longer coincides with what the author meant; verbal meaning and mental meaning have different destinies, .... the text may explode the world of its author. ... The peculiarity of ... the work as such is . . . to transcend its own psycho-sociological conditions of production and thereby to open itself to an unlimited series of readings, themselves situated in socio-cultural contexts which are always different. In short, the work decontextualises itself, from the sociological as well as the psychological point of view, and is able to recontextualize itself differently in the act of reading" (1981: 91). And we should add: in the act of composing also, and, subsequently, of being listened to. (Such decontextualisation / recontextualisation seems to be the central idea of Osborne's Choralis I, II, III.)

A fragment from the text of my duodrama for mezzo-soprano and pianist, entitled Thisness, might be understood also as an instance of de-and recontextualisation (and also that of deconstruction and 
synthesis). It is the fifth of ten parts that constitute the entire text.

\section{Vertigo}

Reeling

rolling
$\begin{aligned} & \text { into the cracks ... } \\ & \text { of words ... }\end{aligned}$

Failing

falling

along an arc ...

along an arc ... a long arc ... arc along ...

arca long ... Canor arca ... conar ... racon ...

Lone agon ... wrong agon ... agonarch ... angor

agon ... racon ...

angor agon, agonal, galga agon, agonarch, galga arc golag, galga lagōr golag, langōr golag, galga long glagola golag, galga golag, galga galör glagola golag, galga galōr glagolag, cama golag. cama galga golag, glagola galgal golag, glagola gorgōn golag, gorgōn agon golag, carna gorgōn agon, carna agon gonal agolag, archōn agolag, archōn golag, agonal, archōn agon golag galac, golag glagolag, glogal golag, golan agon, golan agon, golan agon canān, golan canān agon, galga canān, agon, angor agon, agon, galga golgal, can cana agon, cana agon, cana galga agon, angor agon golag, galga lagōr glagolag, galgal anarch, archōn anarch ... orgōn anarch ... anarch ... anarch ... a narc ... a nare ... narc ... narc ... narc ...

narc ... narca long ...

$|\alpha|$ IA

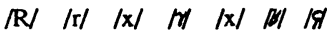

II $/ \mathrm{n} /$

h/

Logar ... arcan logar ... arca long ... a

long arc ...

Figure 2. : 
This text, which, after the first appearance of the phrase 'along an arc . . .,' uses (apart from the few paralinguistic sounds indicated in phonetic script) the restricted phonemic repertory of this single phrase only, was composed to evoke a number of contexts, through the use of certain 'code-words', or their approximations (such as, for example, 'golag' instead of 'gulag', 'angor' for its meaning in Latin - pressing together of the gullet, throttling - and also connoting anger, 'agon' standing for contest and also for agony, etc.). If, indeed, this does take place in the minds of listeners, the end result of such a 'creative listening' might be the imagining of alternative superordinate contexts that may be thought of as accommodating many or all the subordinate ones which the listener has become cognizant of. ${ }^{7}$

From guesses about what might be going on in the mind in some situations we proceeded towards the text. Considerations about the text led us to the context. The next logical step could be one that would lead us to the setting, the composition itself and what the whole weave might mean. Presently, there seems to be no alternative to being idiosyncratically subjective, and arbitrarily selective, when contemplating such a huge and complex maze as this one. You will not expect me to produce here a ground plan for this labyrinth, and I shall refrain from pretending that I have one. But what we do have are our compositional and critical acts, our preferences and commentaries, and these might have some bearing on what one's own labyrinth, and some of those of one's colleagues, might be like.

Erik Bergman in his Noa severely reduced the biblical text to a few nouns and the single sentence: "I am". This Giacometti-like elimination imparts to the work a starkness and strength. One senses the "white spaces' between the words, as many 'holes', which are 'filled' by Bergman's music to strong effect.

Richard Orton's Sawlo Seed is an arcanum in miniature. Its text, Shakespeare's Sonnet XII, is concealed in the work through a simple process of overprinting, resulting in a strange-looking script. Here is a part of what Orton says about the process and its purpose: "I felt there

7 For further comment on Thisness see my 'Thisness: Marks and Remarks' in J. Beckwith, and F.A. Hall eds. Musical Canada (Toronto: University of Toronto Press, 1988), pp. 211-31. 
was a mystery involved in the cipher-shapes themselves - of a meaning hidden beyond the façade ... Perhaps, one could reverse the earlier process; by overprinting, and the human agency, the print might once again become magical sound, the transforming Word. Thus would the performer become an alchemist, an alchemical musician, transforming the dross of the printed word into a living sound, himself becoming transformed in the process" (Notes in the score). Here we have an example of concealment as potential means for revelation.

Odile Marcel in a recent article about Maurice Ohana's use of text writes this: "A partir, des annés 60, Maurice Ohana se déclare l'ennemi du langue. Il part en guerre contre lui, dans des auvres qui évacuent le mot ou n'utilisent d'éléments linguistiques que pulverisés" (Marcel, 1986: 93). "Le discrédit de la conscience et le refus de la psychologie traditionelle justifient qu' on se défie des mots" (Ibid.). Should Marcel be right, we have here an example for a creative act brought about by the device of text-destruction, the whole signifying perhaps a critique or a protest.

Now we may pose the question: under what circumstances is the use of a surrogate language (drum language, for example), and/or silence, warranted as musical signifiers? For instances of these I shall refer to my opera Winthrop, which was premiered in 1986. The work is about John Winthrop, the founder of Boston in New England. While composing the piece I realized, that, although the story is told from the viewpoint of the settlers, and John Winthrop in particular, not to portray the Indians of the colony in the work would not amount to an innocent omission, but to the conspicuous evidence of bias and falsification. So, they had to be included. But how? Could I ever hope to be able to 'speak' fairly and authentically on their behalf? I concluded that I am unable to do this. What is the alternative then? What I ended up doing was to depict the Indians entirely from the vantage point of the fear and distrust, the relative disinterest, and at times the cruelty, which the settlers felt towards and perpetrated against them. This is, then, what occurs in the work. A mysterious distant drumming is heard by the voyagers as their vessel approaches the coastline of America, fringed by the untamed forest; this puts foreboding and fear into their hearts. This drumming persists through much of an entire scene (which is the first one of Act 2). In a later scene Indian sachems, in a wordless cortège, pass by Boston, and we hear hostile exclamatory comments regarding them uttered by the settlers. The march is a droll, pseudo-exotic kind; both music and words convey the expression of a mutual lack of understanding and distrust, and on the part of the Bostonians at least, also of disdain. (The wordlessness 
of the Indians here is a purposeful act. It is the manifestation of a resolve not to depart from silence. It is a strong gesture.) Lastly, after the Bostonians had attacked and mortally wounded a large segment of the Pequot tribe in an allegedly punitive raid, we hear the inarticulate sounds of dying men and women. This is followed by a piercing wailing by another group of women, a kind of ululation of grief. These are the sole instances of vocal sounds the Indians make in the opera.

We considered text, context and touched upon the 'work' itself. A link is missing: the one who listens and responds. Michael Polanyi, who seemingly was equally at home in science and in philosophy, propounded a broad view when suggesting in The Tacit Dimension(1966) the idea of 'tacit knowing': we seem to understand more than what we think we know, and are able to demonstrate that we know it. We all chart our way in this vast labyrinth of texts, contexts, situations and horizons, and even add a wrinkle, or two, to it. We compare notes with each other. And while we do this, we also hear voices that say that, basically, we might be alone. It was Isaac Luria, the teacher in Safed, who put it this way:

... every word of the Torah has six hundred thousand 'faces', that is, layers of meaning or entrances, one for each of the children of Israel who stood at the foot of Mount Sinai. Each face is turned toward only one of them; he alone can decipher it. Each man has his unique access to Revelation.

[G. Scholem, 1965: 13]

Yes, one reads, and re-reads; listens and listens again. We accept the new on occasions, and on other occasions we refuse access to it. We keep on working on the loom; there is no alternative, as Arachné's example shows. Do you recall Arachné's story as retold by Ovid? The master-weaver girl, the proud one, who did not shrink from the challenge to a weaving contest issued by none other than Pallas Athene, herself. Brazen girl, poor, wonderful Arachné; she was turned into a spider by the vengeful goddess with the destiny to spin forever in concert with her descendants ... Y Yes we recognize her as one of us, and ourselves as parts of her, and recall also, with a thought that comes from 
the heart, the theme of the marvellous tapestry she wove for that memorable occasion. ${ }^{8}$

\section{REFERENCES}

ANHALT, I.

1983: Winthrop. score. Toronto: Canadian Music Centre

1984: Alternative Voices Essays on Contemporary Vocal and Choral Composition. Toronto: University of Toronto Press.

1986: Thisness. score. Toronto: Canadian Music Centre.

1988 "Thisness: Marks and Remarks" in Beckwith, J. and Hall, F.A. eds., Musical Canada. Toronto: University of Toronto Press. pp.211-31.

BERIO, L., SANGUINETI, E.

1976: laborintus II. score. Milano: Universal Editions.

BUNGE, M.

1985: Treatise on Basic Philosophy. Vol. 7. Dordrecht-Holland/ Boston - U.S.A.: D. Reidel Publishing Co.

CHATMAN, S.

1981 "How Do We Establish New Codes of Verisimilitude"in Steiner, W. ed. The Sign in Music and Literature. Austin: University of Texas Press. pp.26-38.

ERNOUT, A. et MEILLET, A.

1932: Dictionnaire Etymologique de la Langue Latine. Histoire Des Mots. Paris: Librarie C. Klincksieck.

FOUCAULT, $M$.

1973: The Order of Things An Archaelogy of the Human Sciences. New York: Vintage Books.

GADAMER, H.-G.

1975 Truth and Method. New York: The Seabury Press.

8 I first wrote this text for, and read it at, The Royal Musical Association's 22nd Annual Conference, on 'Words and Music' held on April 10-12, 1987 at Westfield College, University of London. The present one is a slightly altered version of that original paper. 
HJELMSLEV, L.

1969: Prolegomena to a Theory of Language. Madison, Milwaukee, and London: University of Wisconsin Press.

JAKOBSON, R.

1968: Child Language Aphasia and Phonological Universals. The Hague, Paris: Mouton.

MARCEL, ODILE.

1986: "Maurice Ohana: L'Usage de la Parole," in La Revue Musicale, Nos. 391-393: 87-105.

MARCHANT, J.R.V. and CHARLES, J.F. et al.

1955: Cassell's Latin Dictionary. revised, London, Toronto, Melbourne and Sydney: Cassell and Co. Ltd.

OGDEN, C.K. and RICHARDS, I.A.

1946: The Meaning of Meaning. 8th ed. New York: Harcourt, Brace and World, Inc.

ONIANS, R.B.

1951: The Origins of European Thought About the Body, the Mind the Soul, the World Time and Fate. Cambridge at the University Press.

POLANYI, $M$.

1966: The Tacit Dimension. Garden City, New York: Doubleday and Co. Inc.

RICOEUR, P.

1981: Hermeneutics and the Human Sciences. Cambridge: Cambridge University Press.

SCHOLEM, G.

1954: Major Trends in Jewish Mysticism. 3rd ed. New York: Schocken Books.

1965: On the Kabbalah and its Symbolism. London: Routledge and Kegan Paul.

1974: Kabbalah. New York: Quadrangle/The New York Times Book Co.

1987: Origins of the Kabbalah. The Jewish Publication Society, Princeton University Press. 
SEWELL, E.

1964: The Human Metaphor. Notre Dame, Indiana: University of Notre Dame Press.

URBACH, E.E.

1987: "Torah" in Eliade, M. ed. in chief, The Encyclopedia of Religion Vol 14. New York: Macmillan Publishing Co., London: Collier MacMillan Publishers. pp. 556-65.

YATES, F.

1966: The Art of Memory. London: Routledge and Kegan Paul. 